\section{Discussion}

This study provides a clear relation between the mortality rate after recovery from diarrhoea and the nutritional state. Severely malnourished children had a 14 times greater risk of death than their nutritionally better off counterparts. More of the excess deaths occurred within three months after discharge from hospital. Chen et al, in their study of children aged 13 to 23 months followed up for two years in a similar rural community, also found a relation between anthropometric measurements and subsequent mortality. ${ }^{3}$

Interestingly, in our study the excess deaths were confined to the 2 year age group. In children aged less than 2 years there were no excess deaths, nor was mortality affected by nutritional state. By contrast, in the 2 year age group all the deaths occurred in lower nutritional categories. An explanation for these differences might be that nutrition in children aged under 2 years is related to birth weight, whereas malnutrition in children aged 2 years and over is related to food. Also breast feeding is universal and prolonged in this area, ${ }^{7}$ which might have protected the children aged under 2 years against reinfection and contributed to nutritional rehabilitation. Children aged 2 years or more are dependent on other types of food and are neither protected against reinfection nor have sufficient or appropriate food to be rehabilitated nutritionally. Therefore, when a population is universally breast fed, classification of children by single years or even half a year will be methodologically better for nutritional studies.

Another finding, based on lay reporting of causes of death, shows that even in severely malnourished children death occurs after a prolonged illness, mostly of an enteric nature. This would allow enough time for treatment of the disease as well as for nutritional rehabilitation to prevent such deaths.

Our findings indicate a need to integrate diarrhoeal treatment with nutritional rehabilitation and home follow up care for children aged 2 years and severely malnourished. Since death is not immediate, the programme should be implemented easily and successfully.

This research was supported by the International Centre for Diarrhoeal Disease Research, Bangladesh (ICDDR,B). ICDDR,B is supported by countries and agencies which share its concern about the impact of diarrhoeal diseases on the developing world. Current donors giving assistance to ICDDR,B are: Arab Gulf Fund, Australia, Bangladesh, France, Japan, Saudi Arabia, Sweden, Switzerland, United Kingdom, and USAID.

\section{References \\ ${ }^{1}$ Puffer RR, Serrano CV. Patterns of mortality in childhood. Washington, DC: Pan American Health Organisation, World Health Organisation, 1973. \\ 2 Somer A, Loewenstein MS. Nutritional status and mortality: a prospective validation of the quack stick. Am $\mathcal{f}$ Clin Nutr 1975;28:287-92. \\ ${ }^{3}$ Chen LC, Chowdhury AKMA, Huffman SL. Anthropometric assessment of energy protein malnutrition and subsequent risk of mortality among pre-school aged children. Am f Clin Nutr 1980;33:1836-45. \\ ' Ruzicka LT, Chowdhury AKMA. Demographic surveillance system- Matlab. Vol 1. Method and procedures. Dacca: International Centre for Diarrhoeal Disease Research, Bangladesh, 1978. (Scientific report No 9.) \\ 'US Department of Health, Education, and Welfare, Public Health Service. NCHS growth curves for children, birth-18 years, United States. Washington, DC: DHEW, 1980. (DHEW publication No (PHS) 78-1650.) \\ ${ }^{6}$ Samad A, Sheikh K, Sardar AM, Beeke S, Chen LC. Demographic surveillance system-Matlab. Vol 6. Vital events and migration-1977. Dacca: International Centre for Diarrhoeal Disease Research, Bangla- desh, 1979. (Scientific report No 18.) \\ ' Huffman SL, Chowdhury AKMA, Chakraborty J, Simposon NK. Breastfeeding patterns in rural Bangladesh. Am f Clin Nutr 1980;33 144-54.}

(Accepted 26 fuly 1983)

\title{
Comparison between penicillamine and sulphasalazine in rheumatoid arthritis: Leeds-Birmingham trial
}

\author{
V C NEUMANN，K A GRINDULIS，S HUBBALL，B MCCONKEY， V WRIGHT
}

\begin{abstract}
Sulphasalazine was first formulated by Svartz in the early 1940s, specifically for use as a remission inducing drug in rheumatoid arthritis. After the publication of an unfavourable trial, however, the drug was restricted to patients with ulcerative colitis. In the late 1970 s sulphasalazine was re-examined in rheumatoid arthritis and favourable results reported in "open" trials. A double blind controlled trial was therefore conducted comparing enteric coated sulphasalazine and $D$-penicillamine in patients with active rheumatoid arthritis.
\end{abstract}

A total of 63 patients were recruited in two centres; 31

Rheumatism Research Unit, University of Leeds, Leeds LS2 9PJ

V C NEUMANN, MB, MRCP, senior registrar

V WRIGHT, $M D$, FRCP, professor

Dudley Road Hospital, Birmingham

K A GRINDULIS, $M B$, MRCP, registrar

S HUBBALL, BSC, AIMLS, research scientist

B MCCONKEY, DM, FRCP, consultant physician

Correspondence to: Dr V C Neumann. were treated with sulphasalazine and 32 received penicillamine. After 16 weeks' treatment both drugs had produced significant improvements in clinical score, pain score measured on a visual analogue scale, grip strength, Ritchie articular index, erythrocyte sedimentation rate, and serum $C$ reactive protein concentration. Nausea was the major side effect in the sulphasalazine treated group. No potentially dangerous effects of sulphasalazine were encountered in contrast with those seen in the penicillamine group.

The results suggest that sulphasalazine is an effective and safe drug capable of producing remissions in active rheumatoid arthritis. They also lend confidence to the use of preliminary "open" trials as a means of screening for remission inducing drugs in rheumatoid arthritis.

\section{Introduction}

In 1938 contemporary medical thinking held that rheumatoid arthritis was an infection and therefore potentially responsive to antibiotics. Attempts to treat the disease with sulphonamides (the only antibiotics then available), however, had failed. Salicylates were widely used for relief of symptoms but had little 
long term effect on the disease. Professor Nanna Svartz therefore set out on a deliberate attempt to synthesise a drug combining sulphonamide with salicylate. Her work in collaboration with E Askelof and H Willsteadt resulted in the synthesis of sulphasalazine. ${ }^{1}$ Sulphasalazine had the additional property of being specifically concentrated in connective tissue-the site of the pathological process in rheumatoid arthritis-unlike the pure sulphanilamide parent drug. Between 1941 and 1945 Svartz used sulphasalazine in over 400 cases of rheumatoid polyarthritis and reported a favourable result in $63 \%{ }^{2}$ After publication in 1948 of a trial which compared sulphasalazine unfavourably with gold, ${ }^{3}$ however, interest in the drug by rheumatologists waned. Use of the drug was confined to ulcerative colitis until, for different reasons, we re-explored its effects in rheumatoid arthritis. ${ }^{4}$ Early encouraging results ${ }^{4-6}$ provoked the following controlled comparison of penicillamine with sulphasalazine.

\section{Patients and methods}

The trial was conducted at the Dudley Road Hospital, Birmingham, and at the Rheumatism Research Unit, Leeds. Sixty three outpatients were studied, 32 in Birmingham and 31 in Leeds. Forty five were women and $18 \mathrm{men}$. Their mean age was 55 years (range 27-70), the mean duration of their disease was 9 years (range 6 months to 31 years). Twenty nine patients had nodules and all but four had rheumatoid factor titres (latex test) of $1 / 40$ or greater. Each patient gave informed consent before enrolment into the study.

All patients had "active" disease, defined as the presence of at least three of the following (one of which was either $(e)$ or $(f)):(a)$ tenderness of more than three joints; (b) swelling of more than three joints; (c) morning stiffness; (d) articular index more than 20 (Ritchie); (e) erythrocyte sedimentation rate more than $28 \mathrm{~mm}$ in first hour; $(f) \mathrm{C}$ reactive protein concentration more than $20 \mathrm{mg} /$.

Patients with other medical conditions likely to influence or be

TABLE I-Clinical details of the 63 patients with rheumatoid arthritis $(R A)$ randomised to sulphasalazine or penicillamine

\begin{tabular}{lccccccc}
\hline & \multirow{2}{*}{$\begin{array}{c}\text { No of } \\
\text { patients }\end{array}$} & $\begin{array}{c}\text { Mean age } \\
\text { (years) }\end{array}$ & \multicolumn{2}{c}{ Sex } & F & $\begin{array}{c}\text { Mean duration } \\
\text { of RA (years) }\end{array}$ & $\begin{array}{c}\text { No with } \\
\text { RAtre }>1 \text { latex test }\end{array}$ \\
\hline $\begin{array}{l}\text { Sulphasalazine } \\
\text { Penicillamine }\end{array}$ & 31 & 58 & 10 & 21 & 9 & 29 \\
\hline
\end{tabular}

TABLE II-Disease activity at start of treatment

\begin{tabular}{lcc}
\hline & Sulphasalazine & Penicillamine \\
\hline Mean pain score & 64 & 52 \\
Mean duration of morning stiffness (min) & 112 & 88 \\
Mean grip strength (mm Hg) & 96 & 101 \\
Mean articular index & 27 & 24 \\
Mean erythrocyte sedimentation rate in first & 57 & 57 \\
hour (mm) & 49 & 48 \\
\hline
\end{tabular}

influenced by sulphasalazine or penicillamine were excluded, as were patients who had previously received these drugs or another long term agent during the preceding three months. Five patients were taking oral prednisolone $7.5 \mathrm{mg}$ daily or less. The doses were kept constant throughout.

Allocation to sulphasalazine or penicillamine was made using a random number sequence, ensuring that about equal numbers of patients were entered into each treatment group at each centre. Patients given sulphasalazine took enteric coated tablets $500 \mathrm{mg}$ daily for the first week, the dose then being increased by $500 \mathrm{mg}$ increments at weekly intervals to a maintenance dose of $2 \mathrm{~g}$ daily. Patients allocated penicillamine took $125 \mathrm{mg}$ daily for the first two weeks, $250 \mathrm{mg}$ daily for the next two weeks, $375 \mathrm{mg}$ daily for four weeks, and a final divided daily maintenance dose of $500 \mathrm{mg}$.

The period of the trial was from four weeks before starting one or other drug until four months after. Throughout this period patients took a non-steroidal anti-inflammatory drug, usually naproxen. Patients who withdrew after less than four weeks of treatment were replaced, whereas those who stopped later were not. Outpatient visits for assessment were at four week intervals; at each visit side effects were sought and the following clinical measurements made: (a) clinical score (described in full elsewhere ${ }^{7}$; briefly, it entails attaching a score to the patient's response to the question "Do you feel better, worse, or the same?"-rising score signifies improvement; all scores standardised to 100 at start of sulphasalazine or penicillamine); (b) visual analogue pain score (using a $10 \mathrm{~cm}$ horizontal scale); (c) duration of morning stiffness; (d) grip strength (mean of six peak pressures, three with each hand); (e) Ritchie articular index. Inquiry about adverse effects was by the question,"Have the tablets upset you in any way ?"

Clinical assessments were made by one observer in each centre, and in Leeds were done by a clinician ( $\mathrm{VN}$ ) who had previously worked in Birmingham, thus minimising differences in techniques between the two centres. All assessments were performed without knowledge of treatment group.

Laboratory measurements at each visit were the erythrocyte sedimentation rate (Westergren), serum $\mathrm{C}$ reactive protein concentration (radial immunodiffusion), and quantitative rheumatoid arthritis latex test titre. A biochemical profile was recorded at the start and completion of the study. Urine analysis was performed at each visit.

The Wilcoxon paired rank sum test was used to compare the values of each clinical and biochemical measurement at the beginning of treatment with sulphasalazine or penicillamine with those at each subsequent visit. Only patients still taking either drug were included in this analysis.

\section{Results}

The penicillamine and sulphasalazine treatment groups matched well both in clinical characteristics (table I) and in disease activity (table II) at the start of the study.

Efficacy-During the first four weeks of the study, when patients were taking anti-inflammatory drugs alone, there was little change in clinical and laboratory observations. After the introduction of sulphasalazine or penicillamine, however, there were improvements in all clinical and laboratory measurements of disease activity (tables III, IV). There were also some minor changes in haematological measurements (table V). In the sulphasalazine treated group significant

TABLE III-Results of clinical measurements. Values are means (SE in parentheses). [No of observations given in square brackets]

\begin{tabular}{|c|c|c|c|c|c|c|c|c|c|c|}
\hline \multirow[b]{2}{*}{ Week } & \multicolumn{5}{|c|}{ Sulphasalazine } & \multicolumn{5}{|c|}{ Penicillamine } \\
\hline & $\begin{array}{c}\text { Articular } \\
\text { index }\end{array}$ & $\underset{\text { score }}{\text { Clinical }}$ & $\begin{array}{c}\text { Grip strength } \\
(\mathrm{mm} \mathrm{Hg})\end{array}$ & $\begin{array}{c}\text { Morning } \\
\text { stiffness } \\
\text { (min) }\end{array}$ & $\begin{array}{c}\text { Visual } \\
\text { analogue } \\
\text { pain score }\end{array}$ & $\begin{array}{c}\text { Articular } \\
\text { index }\end{array}$ & $\underset{\text { score }}{\text { Clinical }}$ & $\begin{array}{c}\text { Grip strength } \\
(\mathrm{mm} \mathrm{Hg})\end{array}$ & $\begin{array}{c}\text { Morning } \\
\text { stiffness } \\
\text { (min) }\end{array}$ & $\begin{array}{c}\text { Visual } \\
\text { analogue } \\
\text { pain score }\end{array}$ \\
\hline-4 & $26 \cdot 7(1 \cdot 8)$ & $101 \cdot 2(0 \cdot 3) t$ & $96 \cdot 5(4 \cdot 6)$ & $112 \cdot 1(17 \cdot 6)$ & $63 \cdot 8(3 \cdot 8)$ & $24 \cdot 4(2 \cdot 5)$ & $100 \cdot 2(0 \cdot 4)$ & $100 \cdot 8(9 \cdot 6)+$ & $87 \cdot 8(14 \cdot 6)$ & $51 \cdot 3(4 \cdot 7)$ \\
\hline 0 & $28 \cdot 0(2 \cdot 6)$ & $100 \cdot 0$ & $95 \cdot 3(4 \cdot 9)$ & $121 \cdot 9(22 \cdot 7)$ & $66.8(3.8)$ & $24.7(3 \cdot 0)$ & $100 \cdot 0$ & $109 \cdot 4(9 \cdot 8)$ & $107 \cdot 2(19 \cdot 1)$ & $54 \cdot 4(4 \cdot 6)$ \\
\hline 4 & $24 \cdot 1(2 \cdot 6)^{*}$ & $100 \cdot 1(0.4)$ & $101 \cdot 5(6 \cdot 1)$ & $107.5(21.5)$ & $61.9(4 \cdot 6)^{*}$ & $24 \cdot 2(3 \cdot 0)$ & $100 \cdot 1(0.4)$ & $105 \cdot 5(9 \cdot 9)$ & $108 \cdot 9(21 \cdot 7)$ & $49 \cdot 2(4 \cdot 6)$ \\
\hline 8 & $22 \cdot 6(2 \cdot 5)+$ & $101 \cdot 0(0.5)$ & $103 \cdot 3(6 \cdot 2)$ & $83.1(21.5)+$ & $51 \cdot 6(5 \cdot 1)+$ & $23 \cdot 0(3.2)$ & $101.5(0.5)+$ & $113 \cdot 2(11 \cdot 2)$ & $60.9(15 \cdot 2)+$ & $41 \cdot 3(4 \cdot 3)+$ \\
\hline 12 & $15.9(2.4) \dagger$ & $102 \cdot 3(0 \cdot 7)+$ & $120.3(8.9)+$ & $58.7(19.3) \dagger$ & $41 \cdot 7(5 \cdot 2) \dagger$ & $17 \cdot 5(2 \cdot 7)$ & $102 \cdot 4(0.9)^{*}$ & $119 \cdot 2(13.9)$ & $49 \cdot 0(17 \cdot 4)+$ & $37.5(6 \cdot 2)+$ \\
\hline 16 & $\begin{array}{c}17 \cdot 7(3 \cdot 1)+ \\
{[23]}\end{array}$ & $\begin{array}{c}103.7(0.9)+ \\
{[23]}\end{array}$ & $\begin{array}{c}125 \cdot 2(8 \cdot 9)+ \\
{[23]}\end{array}$ & $\begin{array}{c}48 \cdot 3(18 \cdot 6)+ \\
{[23]}\end{array}$ & $\begin{array}{c}37 \cdot 1(5 \cdot 1)+ \\
{[23]}\end{array}$ & $\begin{array}{c}16 \cdot 5(2 \cdot 6)^{*} \\
{[20]}\end{array}$ & $\begin{array}{c}103 \cdot 1(1 \cdot 2) \\
{[20]}\end{array}$ & $\begin{array}{c}121 \cdot 3(17 \cdot 5) \\
{[20]}\end{array}$ & $\begin{array}{c}42 \cdot 0(12 \cdot 2) \dagger \\
{[20]}\end{array}$ & $\begin{array}{c}33 \cdot 7(5 \cdot 1)+ \\
{[20]}\end{array}$ \\
\hline
\end{tabular}

Compared with values at week $0: * p<0.05 ;+p<0.01$. (Wilcoxon paired rank sum test.) 
improvements in the articular index and duration of morning stiffness were seen after four weeks' treatment, when the sedimentation rate and serum $\mathrm{C}$ reactive protein concentration had also fallen; all measurements had improved significantly after 12 weeks. Clinical and laboratory improvements occurred more slowly in the penicillamine treated group, but by the end of the study all measurements apart from grip strength had also improved significantly in that group. Four patients receiving sulphasalazine and three receiving penicillamine reverted from seropositive (rheumatoid arthritis latex test titre 1/40 or greater on both occasions before treatment) to seronegative. A significant fall in latex test titre had occurred with both drugs by 16 weeks $(p<0.01)$.

Tolerance-Two patients "decided not to take part" in the study after less than four weeks' treatment with sulphasalazine or penicilla-mine. One further patient was withdrawn after four weeks' treatment with penicillamine when he developed haematuria. On further investigation this man was found to have a bladder carcinoma. All three patients were replaced. Twelve patients taking penicillamine (five at Leeds, seven at Birmingham) and eight taking sulphasalazine (three at Leeds, five at Birmingham) were withdrawn from the study after four or more weeks of treatment. Table VI shows when these patients were withdrawn and why. Biochemical profiles showed no evidence of abnormality with either drug throughout the study.

\section{Discussion}

Results of a pilot study ${ }^{4}$ and of two, more substantial studies ${ }^{5} 6$ had suggested that sulphasalazine had properties which were likely to be useful in rheumatoid arthritis. The next question was how it compared with other treatments. We chose to conduct a randomised controlled trial comparing the drug with penicillamine; such a trial would test the validity of our earlier work and provide information about the relative efficacy and safety of the two drugs. The performance of penicillamine in rheumatoid arthritis has been closely studied; there is no doubt that it is superior to placebo.' In this relatively short randomised controlled trial we did not achieve complete disease remission, but we were able to show significant improvement in 43 of the original 63 patients. The performance of sulphasalazine was similar, and certainly not inferior to that of penicillamine. Thus
TABLE VI-Reasons for withdrawal from study (20 patients)

$\left.\begin{array}{lcc}\hline & \text { No of patients } & \text { No of weeks' treatment } \\ \hline \begin{array}{l}\text { Sulphasalazine: } \\ \text { Nausea/indigestion }\end{array} & 4 & \left\{\begin{array}{l}4(2) \\ 8(2)\end{array}\right. \\ \text { Rash } & 1 & 8 \\ 8 & 4(1) \\ 8(1) \\ 8\end{array}\right)$

* This patient developed thrombocytopenia when penicillamine was reintroduced one month later.

the findings of this study support our earlier conclusion that sulphasalazine is effective in rheumatoid arthritis.

We have previously maintained that open trials conducted under rigidly controlled conditions predict with reasonable accuracy the outcome of controlled trials. This proved correct for dapsone $^{8}{ }^{9}$ and clozic ${ }^{1011}$ and now has further support from this study. Though we managed to eliminate several problems that may arise in multicentre investigations, we believe that the careful open trial in a single centre has certain merits: it is quick, inexpensive, and an invaluable guideline for the design of subsequent controlled trials. Failure to take account of information from open trials may lead to serious errors, as occurred in the 1948 trial of sulphasalazine. ${ }^{3}$ In that trial, despite earlier recommendations sulphasalazine was administered only as a short course-for a mean of 60 days. The conclusion that sulphasalazine had no advantages over bed rest, dietary supplements, and physiotherapy was based on follow up data obtained an average of four and a half months after stopping the drug. Only one of the original 20 patients was still taking sulphasalazine at the time of follow up. With the benefit of hindsight it is puzzling that the trial was influential for so long.

We have commented previously-on the basis of the relation

TABLE IV-Results of laboratory measurements. Values are means ( $S E$ in parentheses). [No of observations in square brackets]

\begin{tabular}{|c|c|c|c|c|c|c|}
\hline & \multicolumn{6}{|c|}{ Week } \\
\hline & -4 & 0 & 4 & 8 & 12 & 16 \\
\hline $\begin{array}{l}\text { Erythrocyte sedimentation } \\
\text { rate in first hour }(\mathrm{mm}) \\
\text { reactive protein }(\mathrm{mg} / \mathrm{l})\end{array}$ & $\begin{array}{c}57 \cdot 1(4 \cdot 3) \\
{[31]} \\
49 \cdot 7(7 \cdot 3) \\
{[31]}\end{array}$ & $\begin{array}{c}S u l \\
52 \cdot 9(4 \cdot 0) \\
{[31]} \\
48 \cdot 3(7 \cdot 6) \\
{[31]}\end{array}$ & $\begin{array}{c}\text { lphasalazine } \\
45 \cdot 9(3 \cdot 6) \dagger \\
{[30]} \\
30 \cdot 2(4 \cdot 3) \dagger \\
{[31]} \\
\text { Penicillamine }\end{array}$ & $\begin{array}{c}36 \cdot 8(3.4) \dagger \\
{[26]} \\
23 \cdot 3(3.5) \dagger \\
{[27]}\end{array}$ & $\begin{array}{c}29 \cdot 4(3 \cdot 1) \dagger \\
{[23]} \\
17 \cdot 6(3 \cdot 8) \dagger \\
{[23]}\end{array}$ & $\begin{array}{c}31 \cdot 9(2 \cdot 9) \dagger \\
{[22]} \\
17 \cdot 5(3 \cdot 6) \dagger \\
{[23]}\end{array}$ \\
\hline $\begin{array}{l}\text { Erythrocyte sedimentation } \\
\text { rate in first hour }(\mathrm{mm}) \\
\mathrm{C} \text { reactive protein }(\mathrm{mg} / \mathrm{l})\end{array}$ & $\begin{array}{c}57 \cdot 4(3 \cdot 9) \\
{[32]} \\
47 \cdot 8(8 \cdot 0)^{*} \\
{[32]}\end{array}$ & $\begin{array}{c}54 \cdot 5(4 \cdot 7) \\
{[32]} \\
38 \cdot 8(7 \cdot 2) \\
{[32]}\end{array}$ & $\begin{array}{c}\text { callamine } \\
53 \cdot 1(4 \cdot 5) \\
{[30]} \\
37 \cdot 4(6 \cdot 8) \\
{[32]}\end{array}$ & $\begin{array}{c}45 \cdot 9(4 \cdot 4)^{*} \\
{[29]} \\
32 \cdot 6(8 \cdot 5) \\
{[29]}\end{array}$ & $\begin{array}{c}36 \cdot 7(5 \cdot 5) \dagger \\
{[24]} \\
25 \cdot 6(9 \cdot 8) \dagger \\
{[25]}\end{array}$ & $\begin{array}{c}38 \cdot 1(5 \cdot 5) \dagger \\
{[20]} \\
13 \cdot 5(3 \cdot 0) \dagger \\
{[20]}\end{array}$ \\
\hline
\end{tabular}

Compared with values at week $0:{ }^{*} p<0.05 ; \dagger p<0.01$. (Wilcoxon paired rank sum test.)

TABLE V-Results of haematological measurements. Values are means ( $S E$ in parentheses). [No of observations given in square brackets]

\begin{tabular}{|c|c|c|c|c|c|c|c|c|}
\hline Week & $\begin{array}{l}\text { Haemoglobin } \\
(\mathrm{g} / \mathrm{dl})\end{array}$ & $\begin{array}{l}\text { Mean cell } \\
\text { volume (f) }\end{array}$ & $\begin{array}{c}\text { White cell } \\
\text { count }\left(\times 10^{9} / 1\right)\end{array}$ & $\begin{array}{c}\text { Platelet } \\
\text { count }\left(\times 10^{\circ} / 1\right)\end{array}$ & $\underset{(\mathrm{g} / \mathrm{dl})}{\text { Haemoglobin }}$ & $\begin{array}{c}\text { Mean cell } \\
\text { volume }(\mathrm{f})\end{array}$ & $\begin{array}{c}\text { White cell } \\
\text { count }\left(\times 10^{\circ} / 1\right)\end{array}$ & $\begin{array}{l}\text { Platelet } \\
\text { count }\left(\times 10^{\prime} / 1\right)\end{array}$ \\
\hline-4 & $11.7(0.3)$ & $79 \cdot 3(1 \cdot 3)+$ & $\begin{array}{c}8 \cdot 1(0 \cdot 3) \\
{[29]}\end{array}$ & $\begin{array}{c}424(35) \\
{[24]}\end{array}$ & $\begin{array}{c}11 \cdot 9(0 \cdot 2) \\
{[32]}\end{array}$ & $\begin{array}{c}83 \cdot 0(1 \cdot 3) \\
{[31]}\end{array}$ & $\begin{array}{c}8 \cdot 6(0 \cdot 4) \\
{[31]}\end{array}$ & $\begin{array}{c}438(30) \\
{[28]}\end{array}$ \\
\hline 0 & $\begin{array}{c}11 \cdot 6(0 \cdot 3) \\
{[31]}\end{array}$ & $\begin{array}{c}78 \cdot 7(1 \cdot 2) \\
{[31]}\end{array}$ & $\begin{array}{c}8 \cdot 0(0 \cdot 4) \\
{[31]}\end{array}$ & $\begin{array}{c}406(25) \\
{[31]}\end{array}$ & $\begin{array}{c}12 \cdot 1(0 \cdot 3) \\
{[32]}\end{array}$ & $\begin{array}{c}83 \cdot 3(1 \cdot 3) \\
{[32]}\end{array}$ & $\begin{array}{c}8 \cdot 9(0 \cdot 4) \\
{[32]}\end{array}$ & $\begin{array}{c}442(28) \\
{[32]}\end{array}$ \\
\hline 4 & $11 \cdot 5(0.3)$ & $78 \cdot 0(1 \cdot 3)$ & $7 \cdot 3(0 \cdot 4)^{*}$ & $377(22)^{*}$ & $11 \cdot 9(0 \cdot 2)$ & $82 \cdot 2(1 \cdot 4) \dagger$ & $7.9(0.3) \dagger$ & $393(25)^{*}$ \\
\hline 8 & $11 \cdot 6(0 \cdot 3)$ & $79 \cdot 3(1.3)$ & $\begin{array}{c}6 \cdot 5(0 \cdot 3) \dagger \\
{[}\end{array}$ & $329(23) \dagger$ & $12 \cdot 0(0 \cdot 2)$ & $81.9(1.4)$ & $\begin{array}{c}7 \cdot 9(0.3) \dagger \\
{[29]}\end{array}$ & $403(31)^{*}$ \\
\hline 12 & $12 \cdot 0(0 \cdot 3)$ & $80 \cdot 3(1.4)^{*}$ & $6 \cdot 8(0.4) \dagger$ & $305(19) \dagger$ & $12 \cdot 2(0 \cdot 3)$ & $81 \cdot 2(1 \cdot 6)$ & $8 \cdot 4(0 \cdot 6)$ & $362(33)$ \\
\hline 16 & $\begin{array}{c}11.9(0.4) \\
{[22]}\end{array}$ & $\begin{array}{c}81 \cdot 6(1 \cdot 4) \dagger \\
{[22]}\end{array}$ & $\begin{array}{c}6 \cdot 8(0 \cdot 4) \dagger \\
{[22]}\end{array}$ & $\begin{array}{c}307(20) \dagger \\
{[20]}\end{array}$ & $\begin{array}{c}12 \cdot 4(0 \cdot 3) \\
{[20]}\end{array}$ & $\begin{array}{c}83 \cdot 2(1 \cdot 5) \\
{[20]}\end{array}$ & $\begin{array}{c}7 \cdot 7(0 \cdot 5) \\
{[20]}\end{array}$ & $\begin{array}{c}339(26) \\
{[19]}\end{array}$ \\
\hline
\end{tabular}

Compared with values at week $0:{ }^{*} \mathrm{p}<0.05 ; \dagger \mathrm{p}<0.01$. (Wilcoxon paired rank sum test.) 
between radiographic changes and the sedimentation rate and serum $C$ reactive protein value-that when a drug induces clinical improvement as well as falls in sedimentation rate and $\mathrm{C}$ reactive protein it is likely to delay the rate of tissue damage in rheumatoid arthritis. ${ }^{12-14}$ If this hypothesis is correct it implies that sulphasalazine belongs to the group of drugs that are used when the disease is not adequately controlled by nonsteroidal anti-inflammatory agents. The best known members of this group are gold and penicillamine. Others are antimalarials, antiproliferatives, and perhaps dapsone. To select a drug from this group we must consider both efficacy and toxicity. Gold and penicillamine are of proved efficacy but have some serious adverse effects; antimalarials, antiproliferatives, and dapsone have not been shown to be better. In contrast, we found in this and our earlier studies ${ }^{4-8}$-in which we gave sulphasalazine to a total of 121 patients with rheumatoid arthritis-that adverse effects, though frequent, were never dangerous. The record of sulphasalazine in ulcerative colitis, too, suggests that it is safe, although reversible male infertility may occur. ${ }^{15}$ If further trials yield similar results the safety record of sulphasalazine will make it the first choice remission inducing drug in rheumatoid arthritis.

We are very grateful for the help and advice given by Dr Howard Bird in the design and execution of this study. We are also indebted to Mrs Patricia Child for secretarial work.

\section{References}

${ }^{1}$ Svartz N. Salazopyrin, a new sulfanilamide preparation. Acta Med Scand $1942 ; 110: 577-98$
2 Svartz N. The treatment of rheumatic polyarthritis with acid azo compounds. Rheumatism 1948;4:180-6.

3 Sinclair RJG, Duthie JJR. Salazopyrin in the treatment of rheumatoid arthritis. Ann Rheum Dis 1948;8:226-31.

- McConkey B, Amos RS, Butler EP, Crockson RA, Crockson AP, Walsh L. Salazopyrin in rheumatoid arthritis. Agents Actions 1978;8:438-41.

5 McConkey B, Amos RS, Durham S, Forster PJG, Hubball S, Walsh L. Sulphasalazine in rheumatoid arthritis. Br Med f 1980;280:442-4.

6 Bird HA, Dixon JS, Pickup ME, et al. A biochemical assessment of sulphasalazine in rheumatoid arthritis. $\mathcal{F}$ Rheumatol 1982;9:36-45.

${ }^{7}$ McConkey B, Crockson RA, Crockson AP. The assessment of rheumatoid arthritis. A study based on measurements of the serum acute-phase reactants. $Q \mathcal{F}$ Med $1972 ; 162: 115-25$.

${ }^{8} \mathrm{McC}$ conkey B, Davies P, Crockson RA, Crockson AP, Butler M, Constable TJ. Dapsone in rheumatoid arthritis. Rheumatol Rehabil 1976;15:230-4

- Swinson DR, Zlosnick J, Jackson L. Double-blind trial of dapsone against placebo in the treatment of rheumatoid arthritis. Ann Rheum Dis 1981; 40:235-9.

${ }^{10}$ McConkey B, Amos RS, Billingham MEJ, Constable TJ, Crockson RA, Forster PJG. Rheumatoid arthritis: effects of a new agent (ICI 55,897) on serum acute phase proteins and the erythrocyte sedimentation rate. Ann Rheum Dis 1980;39:18-21.

${ }^{11}$ Davies J, Bacon PA, Hall ND, Ring EFJ. Clozic-a new slow-acting agent in rheumatoid arthritis. In: Therapeutic workshops, communications and panels. XV ILAR international congress of rheumatology, Paris, 1981 Paris: Expansion Scientifique Francaise, 1982. (Abstract 301 : p 149.)

12 Amos RS, Constable TJ, Crockson RA, Crockson AP, McConkey B Rheumatoid arthritis: relation of serum C-reactive protein and erythrocyte sedimentation rates to radiographic changes. $\mathrm{Br} M e d \mathcal{F} 1977 ; \mathrm{i}: 195-7$.

${ }^{13}$ Rushton A, Bird HA, Wright $\mathrm{V}$. Assessment of $x$ ray progression in a controlled therapeutic study using a new visual analogue scoring system. Ann Rheum Dis 1983;42:226.

14 Scott DL, Grindulis KA, Struthers GR, Coulton BL, Popert AJ, Bacon PA. Radiological progression in rheumatoid arthritis. Ann Rheum Dis $1983 ; 42: 226-7$.

15 Levi AJ, Fisher AM, Hughes L, Hendry WF. Male infertility due to sulphasalazine. Lancet 1979 ;ii :276-8.

(Accepted 1 fune 1983)

\title{
Sulphasalazine in rheumatoid arthritis: a double blind comparison of sulphasalazine with placebo and sodium aurothiomalate
}

\author{
T PULLAR, J A HUNTER, H A CAPELL
}

\begin{abstract}
Uncontrolled studies have suggested that sulphasalazine may be an effective second line agent in rheumatoid arthritis. Sulphasalazine was therefore compared with placebo and intramuscular sodium aurothiomalate in 90 patients with active rheumatoid arthritis. After six months' treatment both sulphasalazine and sodium aurothiomalate had produced significant clinical and laboratory benefit, whereas placebo had produced no significant change in any variable. Thirteen patients stopped taking the placebo because of lack of effect
\end{abstract}

University Department of Medicine, Centre for Rheumatic Diseases, Glasgow G4 0EH

T PULLAR, MB, MRCP, registrar

H A CAPELL, MB, MRCP, consultant

Gartnavel General Hospital, Glasgow

J A HUNTER, MB, MRCP, consultan

Correspondence to: Dr T Pullar. whereas only two patients stopped taking sulphasalazine and one sodium aurothiomalate for this reason. The major toxicity encountered in the group treated with sulphasalazine was nausea or vomiting, or both; this may be related to slow acetylator phenotype.

Sulphasalazine appears to be an effective second line agent, and further pharmacokinetic studies might prove useful in diminishing gastrointestinal side effects.

\section{Introduction}

Sulphasalazine (4-pyridyl-(2)-aminosulphonyl-3-carboxy-4hydrobenzol) was introduced by Svartz in 1942 for the treatment of rheumatoid arthritis and ulcerative colitis. ${ }^{1}$ Despite further promising studies ${ }^{2}{ }^{3}$ the drug fell out of favour for the treatment of rheumatoid arthritis after the publication of Sinclair and Duthie's paper in $1948 . .^{4}$ It was not until 30 years later that McConkey et al reported an open study of sulphasalazine in the treatment of rheumatoid arthritis, ${ }^{5}{ }^{6}$ and interest has again developed in the use of the drug for this condition. Bird et al recently screened the drug for "second line" properties and found it to have such qualities.?

To date no placebo controlled studies of sulphasalazine in 